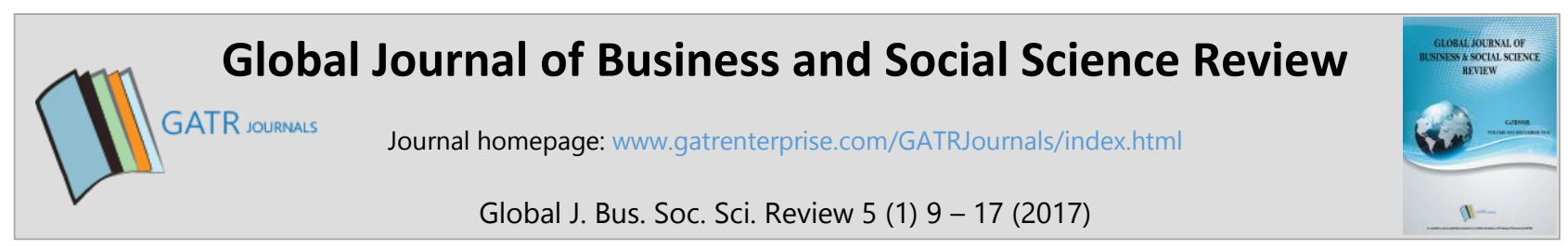

\title{
An Eye View of Technical Communication in English Language among Engineering Students in Southern Tamil Nadu (India): An Analysis in the Postmodern Era
}

\author{
A. Hariharasudan ${ }^{1 *}$, S. Robert Gnanamony ${ }^{2}$ and S. Rajaram ${ }^{3}$ \\ ${ }^{1}$ Assistant Professor, Dept. of English, Kalasalingam University, 626126, Krishnankoil, India \\ ${ }^{2}$ Professor, Dept. of English, Kalasalingam University, 626126, Krishnankoil, India \\ ${ }^{3}$ Associate Professor, Dept. of Business Administration, Kalasalingam University, 626126, Krishnankoil, India
}

\begin{abstract}
Objective -The aim of the research is to cheer the Engineering Students of Southern Tamil Nadu, India to do participative learning in English and facilitate them in obtaining English communication skills for their development in Professional and Career Orientation.

Methodology/Technique - The study was undertaken in India with the sample of 300 students who are in the Engineering colleges of Southern Tamil Nadu. Data had been collected through questionnaire which was later evaluated using SPSS (Statistical Package for Social Sciences) and AMOS (Analysis and Moment Structure) software to validate the conceptual framework.

Findings - The study has revealed the factors affecting LSRW and satisfaction of students. The major factors that are paved the way for this are Professional Purposes, Academic Developments, Personal Developments, Professional Communication Skills, Academic English and Social Communications.

Novelty - This paper will fabricate and determined outline for the development of Engineering Students in Southern Tamil Nadu in the Postmodern Era and encourage them for improving their Professional Communication Skills in English Type of Paper: Empirical.
\end{abstract}

Keywords: Professional Purposes; Academic Developments; Personal Developments; Professional Communication Skills; Academic English; Social Communication; LSRW; Postmodern Era; English.

JEL Classification: I21, D83.

\section{Introduction}

Postmodernists often propose the Globalization or Internationalism theories rather than speaking of Nationalism. The Honourable Prime Minister of India has also put forth provoking innovations concerning the Globalization theory. A recent study (IFRI center for Asian Studies) conducted by Amitendu Palit in 2015,

\footnotetext{
* Paper Info: Revised: September, 2016

Accepted: January, 2017

* Corresponding author:

E-mail: dr.a.hariharasudhan@gmail.com

Affiliation: Department of English, Kalasalingam University, India
} 
"Make in India', is the Prime Minister's signature initiative for transforming India into a global hub for several manufacturing and services industries".

In the age of Globalization, language has become increasingly focused on the needs of global markets. Being a multilingual country with a heritage of unity in diversity, India has many languages used in many different regions especially in Southern Tamil Nadu where almost all of the people are using Tamil as their mother tongue. They give preference to the Tamil language rather any other languages. They fight against the influence of their national language; Hindi. There are some evidential records for "anti-hindi agitations of Tamil Nadu" (Wikipedia: The free Encyclopedia). Even though the Tamil Nadu people fight against the influence of other languages, they willingly accept the impacts of globalization and English in the postmodern era because "English being the most commonly used language in the corporate world, the knowledge of English is one of the most important employability skills. Knowledge of English is much sought after in the corporate world" (Jyothi, 2016). That is why the students of engineering colleges and professionals are placing much more importance on the English language.

When considering the Indian perspective, engineering students' placement in the campus interview mostly depends on their exhibition of English communication skills. From the views of Karnik, former president of NASSCOM (National Association of Software and Services Company), 75 percent of engineering graduates are not eligible for employment in the multinational industries because of their inability to communicate in English (Karnik, 2007, as cited in Rayan 2008, p. 1). Engineering students are one of the most notable target groups for acquiring English proficiency for their technical jobs in multinational industries.

\subsection{Engineering English for Job Orientation}

Multinational Corporations ('MNCs') and major Information Technology ('IT') companies in India employ aspirants of engineering who have fine English communication skills. In this technically developing society, efficiency in English is measured as one of the first and most important employability skills. In other aspects, communicating in English is believed to be the 'life skill' or 'survival skill' in the postmodern era.

There are many factors which contribute to engineering students' lack of efficiency in English and deficit in English communication. The need for developing engineering students' communication skills in order to prepare them for the workplace has been dealt with in a number of places and questions regarding the usefulness of the curriculum in engineering English also have been raised.

\subsection{Problem Statement}

The recruiters of Engineers in India are mostly MNCs, (i.e. Ford, TATA, Wipro, Infosys, HCL Tech, Adani Enterprises, Reliance, Biocon and others) and their clients are from different nations. To satisfy the needs of their clients, the employees of these industries must have excellent communication skills in English; English stands as a global language in the MNCs. However most engineering aspirants are not up to the satisfactory level as Kim said, when speaking of the Korean perspective: "English is used in most international organizations and publications in engineering fields and most engineers whose native language is not English would find disadvantages in their professional terms".

During the selection or employment process in the MNCs, English plays a vital role to the engineers. The engineering students of Tamil Nadu are highly influenced with their native language Tamil so they struggle in finding opportunities from their campus recruitment procedures. This was clearly demonstrated in The New Indian Express (News Portal) by Swaminathan in 2015: "a HR manager working with a renowned automobile company in Coimbatore said, 'When we go for campus recruitment, 80 percent of the jobs are in the service sector, where communication in English is essential. Unfortunately, students from tier-3 cities are not capable of even having a base level conversation in English"'. The problem statement of this paper is to assess the efficiency level of the engineering students of Southern Tamil Nadu. The targeted area is set up with in excess 
of two hundred engineering colleges with a rural background. This assessment would therefore be more useful to aid the progressive upgrade of emerging engineers to attain an industry ready level of English profieicieny.

\subsection{Objectives}

- To determine the opinion of technical communication in English language of the engineering students of Southern Tamil Nadu.

- To analyse influential factors like Professional Purposes, Academic Developments, Personal Developments, Professional Communication Skills, Academic English, Social Communications in the mediating variables Listening, Speaking, Reading and Writing ('LSRW').

- To identify the Overall Satisfaction ('SAT') level of technical communication of English language among the engineering students in Southern Tamil Nadu.

- To suggest technical communication in English language for the engineering students' development in career orientation, entrepreneurship, placement training, and global competencies.

\section{Review of Literature}

There has not been much work done on the technical communication in English among engineering students in Southern Tamil Nadu. There are some earlier studies related to these issues found in various places of India and other non-English speaking countries.

Abdulla and Kumar (2016) stated that communication skills and English language are the prime factor for engineering students' academic and professional life. To satisfy the expectations of MNCs, Indian engineering students need to develop their English communication skills. They suggested that, Indian technical universities and colleges need to integrate technical English into the engineering students curriculum for the entire four years of their studies, rather than giving less priority to the development of their English proficiency.

Devi (2016) pointed out in her study that English is the major determining factor when recruiting job seekers to industries in the modern globalized world. English stands as the lingua franca in MNCs. She states that "English is a means for the acquisition of employment, power and privilege in society". She also concluded that English communication skill is one of the major employability skills in modern India.

The study of Rajprasit and Hemchua (2015) also highlighted the importance of English language in multinational workplace communication in the computer engineering field of Thailand. They concluded that technical knowledge is no longer enough in terms of their job recruitment process because Thai computer engineers now dealt with international clients and colleagues. The findings suggested that in order to effectively function at a global level, their engineers use English efficiently as a tool of communication.

Furthermore, the findings of Tinh (2015) confirm that, English language is important for mechanical engineers in the workplace in the Vietnamese context. He stated that, "English ability and communication skills in English are the only criterion that makes a difference among mechanical engineers". This study also suggested that mechanical engineering students need to prepare well for workplace use in the Vietnamese context.

The study of Nahavandi and Mukundan (2014) set out to determine whether there is any connection between proficiency levels, gender, extra education in language institutes and strategic use of Iranian EFL learners' about learning foreign language in the Iranian perspective. They concluded that, syllabus designers and material developers need to integrate the English language into books, activities and tasks that not only boost the use of learning strategies, but also offer opportunities in using such strategies. The pair mentioned that using language learning strategies are more important than the mere theoretical learning. Their study was fully focussed on the Iranian perspective however, so it may differ from other populace with different ethnic, linguistic, or educational backgrounds. Their study may be taken into account for the purpose of the present study in the Indian context. 
The findings of Sasidharan's (2012) doctoral thesis indicated that, proficiency in English and certain life skills and technical skills related to language learning in English were also important to the engineering students of Orissa (India) for their successful career orientation. She suggested that, technical English and life skills related to teaching and learning English have to be incorporated into the syllabus to face various day to day situations after completing their engineering course.

The study of Meenakshi and Raju (2010) on the use of technology in teaching English to engineering students of India revealed that the students' English language acquisition skills are very effective while using technology. Their study is important in the context of teaching English in India; there are large number of engineering programs that have come into existence in India since the 1950s. According to them, language played a secondary role but things have now changed. They recognised that India has been emerging globally in recent years and as a result, job opportunities for engineering students became global in nature. Their study revealed that the use of technology for teaching and learning English plays a major role when preparing the engineering students for job opportunities.

This literature review shows that the importance of English communication to the engineering students of different places has been studied over the past few years but no such study has been carried out in the engineering colleges of Southern Tamil Nadu until now. This study is different from the other studies. This study will bridge the gap between the above researches. Therefore, the present study can observe the different aspects of differing approaches in the teaching and learning practices of English for engineering purposes. Its findings and implications will definitely be of use to policy makers, English teaching faculty and also for engineering students of Southern Tamil Nadu.

\section{Methodology}

This paper has evaluated the reviews on technical communication in English language among engineering students in Southern Tamil Nadu. In order to test the results of the study, there is a path diagram of the research model displayed below in Figure 1.

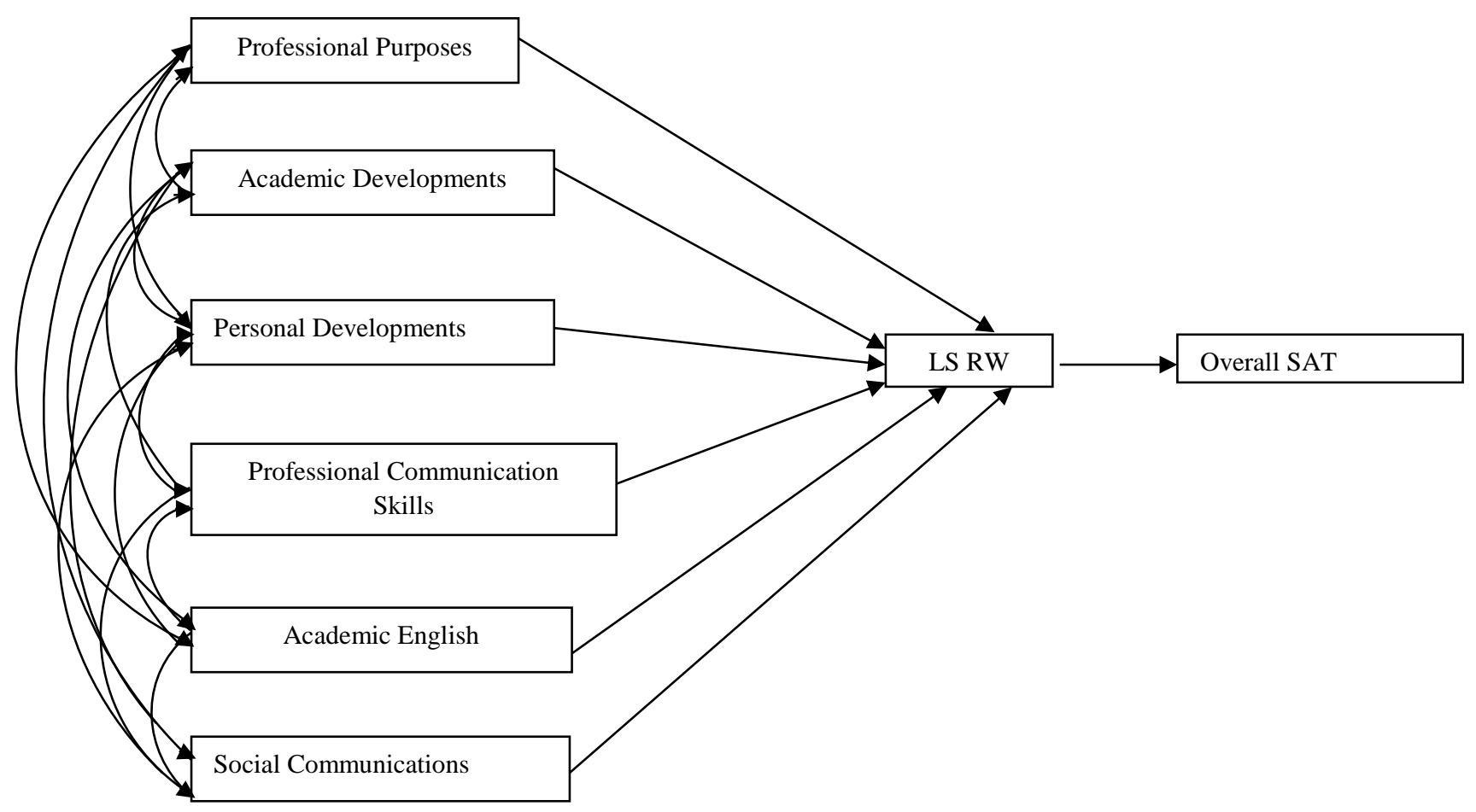

Figure 1: Prosposed conceptual model for the study 
The above proposed conceptual model is tested by using AMOS20 software to test the reliability and fit of the model index. By using the Baysan estimate, the primary data collected for the research is tested as a base parameter of Converge Statistic ('CS'). The above path analysis depicts the causal relationship between cause and effect. The values of cause are; professional purposes, academic developments, personal developments, professional communication skills, academic English, social communications. The mediating variable is LSRW (listening, speaking, reading, writing) and leads to positive or negative impact on overall satisfaction of career orientation, entrepreneurship, placement Ttaining, and global competencies.

Hypothesis of the study are:

- $\mathbf{H}_{1}$ : There is a significant impact of Professional Purposes on LSRW.

- $\mathbf{H}_{2}$ : There is a significant impact of Academic Developments on LSRW.

- $\mathbf{H}_{3}$ : There is a significant impact of Personal Developments on LSRW.

- $\quad \mathbf{H}_{4}$ : There is a significant impact of Professional Communication Skills on LSRW.

- H5: There is a significant impact of Academic English on LSRW.

- $\mathbf{H}_{6}$ : There is a significant impact of Social Communications on LSRW.

- $\mathbf{H}_{7}$ : There is a significant impact of LSRW on overall SAT of the English Language.

\section{Results}

\subsection{Analysis and Interpretation}

Table 1 : Descriptive Statistics Analysis of Sample Size

\begin{tabular}{|l|l|l|l|l|l|}
\hline $\begin{array}{l}\text { Demographic } \\
\text { variables }\end{array}$ & $\begin{array}{l}\text { Frequency } \\
(\mathbf{N = 3 0 0 )}\end{array}$ & $\begin{array}{l}\text { Percentage } \\
\mathbf{( 1 0 0 \% )}\end{array}$ & $\begin{array}{l}\text { Demographic } \\
\text { variables }\end{array}$ & $\begin{array}{l}\text { Frequency } \\
(\mathbf{N = 3 0 0 )}\end{array}$ & $\begin{array}{l}\text { Percentage } \\
(\mathbf{1 0 0 \% )}\end{array}$ \\
\hline Gender & & & Department & & \\
\hline Male & 156 & 52 & Civil & 33 & 11.0 \\
\hline Female & 144 & 48 & Arch & 9 & 3.0 \\
\hline Year & & & Mechanical & 36 & 12.0 \\
\hline I year & 18 & 6.0 & EEE & 30 & 10.0 \\
\hline II year & 210 & 70.0 & EIE & 21 & 7.0 \\
\hline III year & 30 & 10.0 & Biotech & 33 & 11.0 \\
\hline IV year & 14.0 & Auto & 3 & 1.0 \\
\hline & 42 & & CSE & 75 & 25.0 \\
\hline & & & IT & 54 & 18.0 \\
\hline & & & Biomedical & 6 & 2.0 \\
\hline
\end{tabular}

Male respondents made up 52 percent of the sample size while females made up the remaining 48 percent. Whilst 70 percent of the respondents were in their second year of study, the remaining respondents were in their first, third or fourth year. Furthermore, 25 percent of the respondents were CSE students, 18 percent of the respondents were IT and the remaining respresent the departments of Civil, Arch, Mechanical, EEE, EIE, Biotech, Auto, Biomedical.

Table 2: Model Fit Statistics

\begin{tabular}{|l|l|l|}
\hline Model fit statistics & Suggested value & Actual value \\
\hline Chi-square/ df & $\leq 5.00$ & 2.96 \\
\hline Goodness of Fit Index (GFI) & $\geq 0.90$ & 0.920 \\
\hline Adjusted Goodness of fit Index (AGFI) & $\geq 0.80$ & 0.815 \\
\hline
\end{tabular}




\begin{tabular}{|l|l|l|}
\hline Comparative Fit Index (CFI) & $\geq 0.90$ & 0.912 \\
\hline $\begin{array}{l}\text { Root means square of approximate } \\
\text { (RMSEA) }\end{array}$ & $\leq 0.08$ & 0.059 \\
\hline
\end{tabular}

Model fit indices: the Bentler and Bonnet (1980) study indicated that the model fit can be checked by RMSEA (Root Mean Square Error of Approximation), which is less than 0.08, has a good fit and less than 0.05 has a closer fit. The Joreskog and Sorbom (1988) study proposed that GFI (Goodness of Fit Index) should be above 0.9 and AGFI (Adjusted good-of-fit Index) should be above 0.8. A Bentler (1990) study suggested that CFI (Comparative Fit Index) should be greater than 0.9. Wheaton (1987) and Hair et al., (1998) proposed that chi-square should be $<5$ to be acceptable. In the model estimation output, a chi-square value of 2.96 is significant at the $\mathrm{p}<0.001$ level. The value of AGFI (0.815) and CFI (0.912) indicate the adequate fit between the structural model and sample data. The GFI of 0.920 and RMSEA of 0.059 revealed the goodness of fit. This confirms that the available data set moderately fits into the proposed structural model.

\subsection{Impact of Engineering Students' Needs in English lead to Overall SAT}

Clearly, from the empirical research, professional purposes, academic developments, personal developments, professional communication skills, academic English and social communications directly affect LSRW, having a positive as well as negative effect on the satisfaction of engineering students. (See Figure 2)

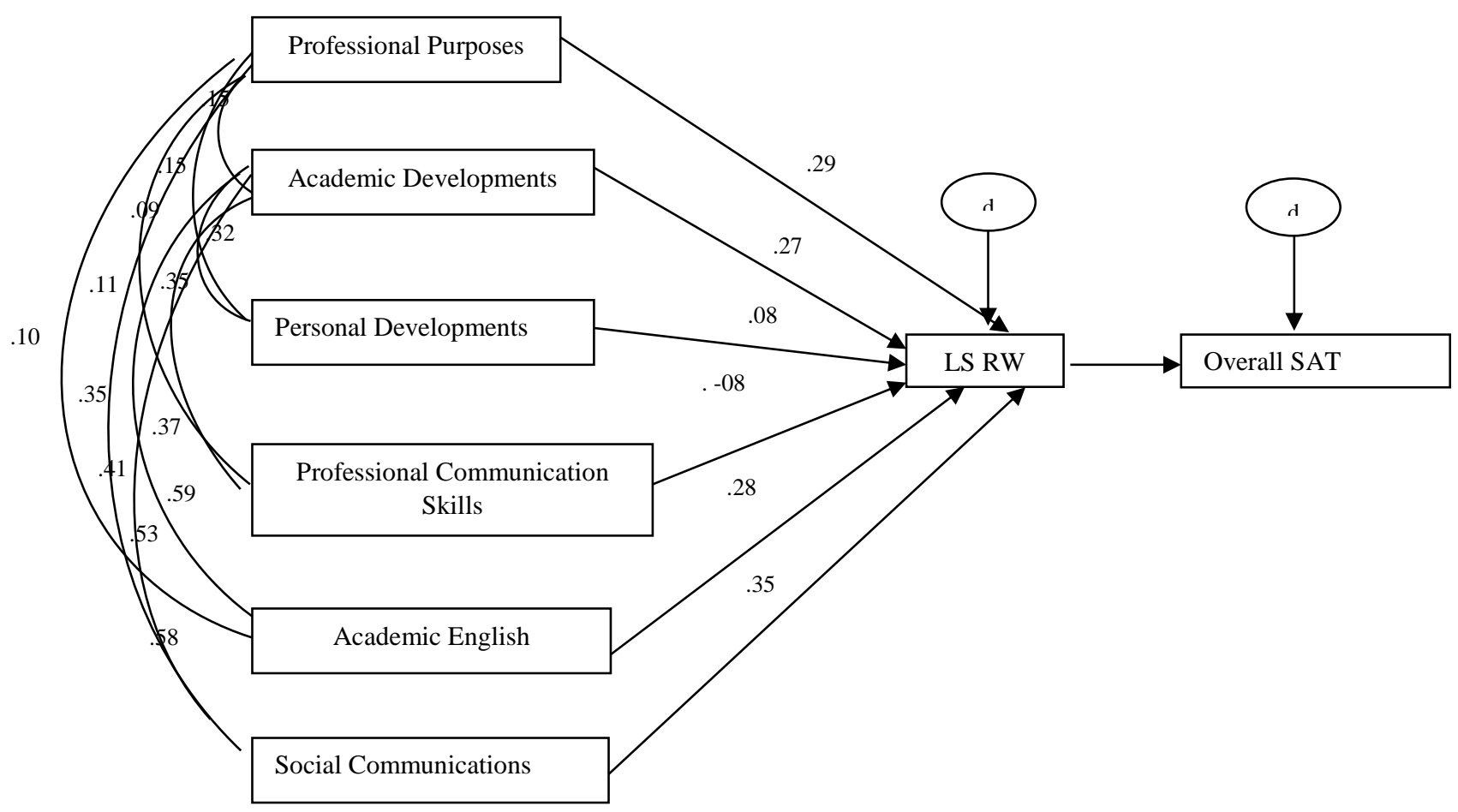

Figure 2: Impact of Engineering Students' Needs in English lead to Overall SAT

Where $\mathrm{d} 1$ and $\mathrm{d} 2$ are the disturbance error terms for exogenous and endogenous variables. 
Table 3 : Empirical Results of the Prosposed Model

\begin{tabular}{|c|c|c|c|c|c|c|c|}
\hline \multicolumn{3}{|c|}{ Structural paths } & Estimate & S.E. & C.R. & $P$ & Hypothesis \\
\hline Professional Purposes & $\rightarrow$ & LSRW & 0.290 & 0.090 & -2.528 & 0.011 & Yes \\
\hline Academic Developments & $\rightarrow$ & LSRW & 0.266 & 0.121 & 2.203 & 0.028 & Yes \\
\hline Personal Developments & $\rightarrow$ & LSRW & 0.077 & 0.096 & 0.796 & 0.426 & Yes \\
\hline $\begin{array}{l}\text { Professional Communication } \\
\text { Skills }\end{array}$ & $\rightarrow$ & LSRW & -0.078 & 0.129 & -0.604 & 0.546 & No \\
\hline Academic English & $\rightarrow$ & LSRW & 0.276 & 0.088 & 3.117 & 0.002 & Yes \\
\hline Social Communications & $\rightarrow$ & LSRW & 0.353 & 0.117 & 3.031 & 0.002 & Yes \\
\hline LSRW & $\rightarrow$ & $\begin{array}{l}\text { Overall SAT of the } \\
\text { English Language }\end{array}$ & 0.820 & 0.091 & 9.016 & $* * *$ & Yes \\
\hline
\end{tabular}

The regression weight represents the degree of association between constructs and manifesting variables. LSRW was influenced by professional purposes (0.290), academic developments (0.266), personal developments (0.077), professional communication skills (-0.078), academic English (0.276) and social communications (0.353). However, professional communication skills and the remaining five exogenous variables have positive regression weights on LSRW. These results are salient in identifying the overall satisfaction of English language proficiency. In continuation, LSRW (0.820) leads to a positive impact on overall satisfaction of English language. It leads to increased usage of the English language for students' development in career orientation, entrepreneurship, placement training, and global competencies. To give a noteworthy result for this study, technical communication in English language yields satisfaction as well as development in career prospects. The inter-correlation between the dimensions like professional purposes, academic developments, personal developments, professional communication skills, academic English and social communication are positively connected to each other.

\section{Discussion of the Study}

This paper is based on the empirical study to validate the technical communication of English language by the mediation effect of LSRW. The study has revealed the factors affecting LSRW and satisfaction of students. The major factors that have paved the way for this are professional purposes, academic developments, personal developments, professional communication skills, academic English and social communications. The degree of relationship between LSRW and the factors are; professional purposes (0.290), academic developments (0.266), personal developments (0.077), professional communication skills (-0.078), academic English (0.276) and social communications (0.353). LSRW has a significant relationship with overall SAT of the English language. The regression weight represents the degree of association as 0.820 .

As a result, it shows that the most influential factors like academic developments, personal developments, academic English, social communications and professional purposes are reflecting positively on the mediating 
variable LSRW, with the exception of professional communication skills. Based on the study, the engineering students of Southern Tamil Nadu need to equip themselves for their future prospects of their career. The development in professional communication skills will lead them to placements in MNCs easily. It is in their best interests to correct their lack of ability in professional communication skills. This will allow them to successfully shine in the postmodern era.

By reading this research article, the base level drawbacks of teaching and learning in tecnincal communication in the English language of the engineering students of Southern Tamil Nadu has been indentified. It is believed that the findings of the study will have an impact on engineering students of Southern Tamil Nadu, course designers, curriculum planners and future engineering students. The engineering students will now understand the consequences of neglecting the development of their English proficiency as well as the importance of English language in their career progression. Their priority to develop Engish skills will be improved, to equal their prioritisation of their technical subjects. Teachers of English will be more enthused by seeing the thirst of the aspiring engineers. These attitutes will lead them to give effective class room teaching of the English language. Change is permanent and accordingly, the engineering students of Southern Tamil Nadu need to better equip themself in the area of professional communication skills as an integral skill for their career progression.

\section{Reference}

Palit, A. (2015). Economics in Narendra Modi’s Foreign Policy. Asie Visions, 77.

Bentler, P.M. (1990) Comparative fit Indexes in Structural Models, Psychological Bulletin, 107(2), 238-246.

Bentler, P.M. and Bonett, D.G. (1980) Significance Tests and Goodness of fit in the Analysis of Covariance Structures', Psychological Bulletin, 88(3), 588-606.

Hair, J.F., Anderson, R.E., Tatham, R.L., Black, W.C. (1998). Multivariate Data Analysis. 5th ed. Upper Saddle River, New Jersey: Prentice Hall, p. 577-666.

Kim, H. H. (2013). A Research on the English for Engineering Students Course Based on Needs Analysis in Korea, Proceedings, The 3rd International Conference on Circuits, Control, Communication, Electricity, Electronics, Energy, System, Signal and Simulation, 25, 45 - 49.

Jöreskog, K. G. y Sörbom, D. (1988). LISREL® 7: A guide to the Program and Applications. (2nd ed.) Chicago, IL: SPSS.

Jyothi (2016), Importance of English in Employment, Deccan Herald, Viewed 26 August, 2016. Retrieved from: http://www.deccanherald.com/content/249714/importance-english-employment.html.

Meenakshi, K. \& Raju, V. (2010). Use of Technology in Teaching English to Engineering Students - A Study of Engineering Programs in India, Proceedings, Conference for Industry and Education Collaboration, American Society for Engineering Education, February 3-5, 2010 Palm Spring California.

Rajprasit, K., \& Hemchua, S. (2015). The English Language \& Communication in the International Workplace: An Examination of Thai Computer Engineering Professionals. 3L: Southeast Asian Journal of English Language Studies, 21(3).

Tinh L. C. (2015), Needs analysis of English for mechanical engineering students in the Vietnamese context, viewed 29 August, 2016. Retrieved from: http://www.vnseameo.org/TESOLConference015/Materials/PPT/Mr.\%20Le\%20Cao\%20Tinh.pdf

Abdulla M.D. \& Kumar, S.A. (2016). Blooming English Language Skills For Budding Engineers To Flourish In Global Environment, Journal of English language and literature. 3(1).

Devi M.R. (2016). English For Employability Of Indian Students, Journal of English language and literature. 3(1).

Nahavandi, N. and Mukundan, J. (2014) Language Learning Strategy Use Among Iranian Engineering EFL Learners. Advances in Language and Literary Studies, 5(5).

Sasidharan, P. (2012). A Needs-Based Approach to Teaching and Learning of English for Engineering Purposes, (PhD Thesis in Humanities and Social Sciences, National Institute Of Technology, Orissa). Retrieved from: http://ethesis.nitrkl.ac.in/4429/1/Priya_S_50713001.pdf.

Swaminathan, R. (2015). The Fault in our Placement Stars, The New Indian Express, Viewed 29 August,2016.Retrieved from:http://www.newindianexpress.com/education/edex/The-Fault-in-our-Placement-

Stars/2015/09/12/article3022773.ece. 
Rayan, A. P. (2008). Assessing Communication Apprehension, Education Express. The New Indian Express, 11 Aug. pp.2.

Wheaton, B. (1987) Assessment of fit in Over Identified Models with Latent Variables. Sociological Methods \& Research, 16(1), 118-154.

Wikipedia The free Encyclopaedia, Anti - Hindi agitations of Tamil Nadu, Viewed 26 August, 2016.https://en.wikipedia.org/wiki/Anti-Hindi_agitations_of_Tamil_Nadu. 